\title{
Pengaruh Latihan Kekuatan Otot Lengan Terhadap KemampuanSmash Dalam Permainan Bola voli
}

\author{
The Effect Of Arm Muscle Strenght Training On Smash \\ Ability in Volleyball Game \\ Heru Sulistiadinata ${ }^{1}$, M. Yogi Aditya ${ }^{2}$, \\ ${ }^{1,2}$ Program studi PJKR, STKIP Pasundan, Cimahi, Jawa Barat, 40512, Indonesia
}

\begin{abstract}
Abstrak
Tujuan penelitian ini bertujuan untuk mengetahui pengaruh latihan kekuatan otot lengan terhadap hasil kemampuan smash dalam permainan bola voli di SMPN 1 BOJONGPICUNG. Penelitian ini menggunakan metode eksperimen. Desain penelitian menggunakan pre-test dan post-test.Teknik pengambilan sampel dalam penelitian ini menggunakan random sampling dengan sampel penelitian berjumlah 30 siswa. Instrument tes yang digunakan dalam penelitian ini adalah tes pull-up dan tes akurasi smash. Analisis data dengan cara statistik deskriptif dengan perhitungan persentase. Hasil penelitian menunjukkan bahwa sebanyak 15 siswa dengan latihan kekuatan otot lengan sebesar 5,6\%, sedangkan peningkatan pemain yang tidak menggunakan latihan kekuatan otot lengan sebesar 3,8\%., maka latihan kekuatan otot lengan memberikan pengaruh yang signifikan terhadap hasil kemampuan smash dalam permainan bola voli.
\end{abstract}

Kata kunci : Smash, kekuatan otot lengan, bola voli

\begin{abstract}
The purpose of this study aims to determine the influence of arm muscle strength exercises on the results of smash abilities in volleyball games at SMPN 1 BOJONGPICUNG. This study uses experimental methods. The research design uses pretest and post-test. Sampling techniques in this study using random sampling with a sample of 30 students. The test instruments used in this study were pull-up tests and smash accuracy tests. Analyze data in a descriptive statistical way with percentage calculations. The results showed that as many as 15 students with arm muscle strength exercises by $5.6 \%$, while the increase in players who did not use arm muscle strength exercises by $3.8 \%$., then arm muscle strength exercises had a significant influence on the results of smash ability in volleyball games.
\end{abstract}

Keywords : Smash, arm muscle strength, volleyball

\section{PENDAHULUAN}

Masa sekarang ini dengan adanya globalisasi yang diikuti dengan kemajuan yang terjadi sampai saat ini (Dr. Bafirman HB, M.Kes. \& Dr. Asep Sujana Wahyuni, S.Si., 2019) Dalam kehidupan sehari-hari segala sesuatu menjadi lebih muda. Mulai dari sistem gerak relaksasi (praktek) maupun dalam sistem tatap muka (teori). Bahkan melalui alat komunikasipun dan transportasi semuanya itu dapat memberikan ruang bebas buat peserta didik baik dalam lingkungan masyarakat maupun dalam pembelajaran di sekolah yang sifatnya dapat memberikan obyek dalam penanaman sikap disiplin. Contohnya handphone memudahkan peserta didik dalam mengakses, menjalani komunikasi antar satu dengan yang lainnya, transportasi sebagai alat penghubung ke tempat satu dengan 
yang lain dalam waktu relative singkat, hingga sampai saat sekarang ini olahraga dalam pembelajaran di sekolah sudah bisa memberikan keleluasaan untuk melakukan olahraga tanpa batasan begitu pun dalam peningkatan prestasi perlu adanya proses yang baik yang harus dilakukan oleh peserta didik.

Dari kutipan diatas sudah sangat jelas yang mengacu ke aturan sistem pembinaan olahraga bagi peserta didik bahwa salah satu yang bisa memberikan prestasi peserta didik itu perlu memperhatikan potensi, minat dan bakat yang dimilikinya (Effendi, 2016) karena tak terlepas dari situlah yang bisa memberikan ruang untuk mendapatkan hasil yang terbaik, namun perlu didukung dengan kesenjangan prosess interaktif dalam pembelajaran teori olahraga dan salah satunya adalah olahraga permainan yang bisa memberikan efek netralisasi, rekreasi dalam belajar.

Melalui hasil pengamatan penulis dengan metode pembelajaran disekolah bahwa dari beberapa teknik dasar bermain bola voli yang telah dipelajari oleh peserta ekstrakulikuler baik itu melalui praktek maupun teori hanya mampu mencapai indeks kumulatif dengan rata - rata kemampuan 20\% dari jumlah 30 orang peserta ekstrakulikuler yang secara keseluruhan dalam melakukan teknik bermain Smash Bola voli. Sedangkan untuk teknik lainnya yaitu Servis, Passing dan Blok kemampuan peserta ekstrakurikuler dalam indeks pencapaian kumulatifnya dengan rata - rata $80 \%$ dari hasi penilaian secara keseluruhan dalam proses pembelajaran ekstrakuriler disekolah SMPN 1 BOJONGPICUNG.

Kondisi dilapangan masih banyak siswa yang kurang kekuatan pukulan dalam permainan bola voli dan latiham kekuatan pukulan masih menggunakan latihan biasa, hal ini masih melakukan latihan mengandalkan pengalaman pelatih itu sendiri. Latihanlatihan yang mengenai kekuatan pukulan banyak bentuk dan jenisnya(Chan, 2012). Latihan kekuatan pukulan bisa dilakukan menggunakan beban atau juga bisa dilakukan dengan stand ball.

Latihan pukulan yang di maksud adalah latihan pukulan dengan menggunakan kekuatan otot lengan. Latihan ini diharapkan mampu untuk meningkatkan kemampuan smash yang berimbas pada peningkatan keterampilan smash (Suarsana \& Baan, 2013). Kondisi fisik merupakan satu prasyarat yang sangat diperlukan dalam usaha peningkatan prestasi seorang atlet, bahkan dapat dikatakan sebagai kebutuhan dasar yang tidak dapat ditunda (Dr. Bafirman HB, M.Kes. \& Dr. Asep Sujana Wahyuni, S.Si., 2019).

Permainan bola voli pada awalnya merupakan olahraga rekreatif, namun bila dilihat dari kenyataan di atas, selain merupakan olahraga rekreatif dewasa ini permainan bola voli juga merupakan olahraga kompetitif. Hal ini sejalan dengan pendapat 
(Beutelstahl, 2015) "Dalam perkembangannya, Kepopuleran olahraga ini tampak dari sarana lapangannya di masyarakat pedesaan, kota, sekolah dan lain-lain. Permainan ini digemari oleh remaja, pemuda maupun dewasa. Gerakan-gerakan yang terdapat dalam permainan bola voli terdiri atas unsur gerakan yang lahir dalam bentuk teknik dasar permainan bola voli. Akan tetapi nilai rekreasi tidak akan hilang bahkan akan selalu melekat".

Permainan bola voli yang mengarah kepada prestasi mengharuskan atletnya untuk memiliki komponen kondisi fisik yang baik, selain harus memiliki teknik taktik dan mental (Ilmiah et al., 2016). Teknik-teknik dasar bola voli yang harus dikuasai oleh pemain bola voli menurut (munizar, razali, 2016), adalah "Permainan bola voli terdiri dari teknik dasar permainan, diantaranya : servis,umpan, smash dan block". Setiap teknik tersebut mempunyai karakteristik dan fungsi yang berbeda, dan dapat dilakukan dengan berbagai cara.

Namun demikian seorang atlet untuk dapat memiliki teknik yang baik secara berkesinambungan saat melakukan teknik saat bermain mereka harus memiliki kondisi fisik yang baik. Hal tersebut sejalan dengan pendapat Harsono (1988:153) yang mengatakan bahwa kalau kondisi fisik individu baik, maka

1. Akan ada peningkatan dalam kemampuan sistem sirkulasi dan kerja jantung;

2. Akan ada peningkatan dalam kekuatan, kelenturan/stamina, kecepatan dan lain lain komponen kondisi fisik;

3. Akan ada ekonomi gerak yang lebih baik pada waktu latihan;

4. Akan ada pemulihan yang lebih cepat dalam organ-organ tubuh setelah latihan.

5. Akan ada respons yang cepat dari organisme tubuh kita apabila sewaktu-waktu respon demikian diperlukan.

Artinya bahwa teknik yang baik harus ditunjang oleh kondisi fisik yang baik pula. Komponen kondisi fisik yang harus dimiliki oleh seorang atlet bola voli sangat bervariasi. Komponen kondisi fisik tersebut adalah kecepatan, kekuatan, power, daya tahan, fleksibilitas dan agilitas. Komponen-komponen kondisi fisik ini diperlukan ketika atlet sedang bertanding.

Sesuai dengan perkembangan ilmu pengetahuan, maka istilah pun kadang kadang berkembang mengikuti fungsi sesuai yang dimaksud dalam pengertian tersebut. Sekarang ini telah berkembang suatu istilah yang lebih populer dari physical build-up, yaitu physical conditioning yang maksudnya adalah pemeliharaan kondisi atau keadaan fisik . 
Faktor yang cukup mendasar ialah kondisi fisik, kondisi fisik yang prima dibutuhkan untuk mempertahankan teknik dalam melakukan spike yang berulang-ulang, terutama kondisi fisik yang mendukung kelangsungan gerak spike yaitu otot-otot lengan. Kontribusi bagian tubuh untuk melakukan spike antara otot lengan dan tungkai pasti berbeda, atau bahkan sama. Berdasarkan pola spike dalam permainan bola voli yang dikemukakan (Seminar et al., 2017) diantara poin melakukan gerak spike menyatakan : "menolakan kaki sekuat- kuatnya kaki ke lantai, dan pukul bola pada bagian atas belakangnya dengan cambukan telapak tangan dan gerakan poros yang aktif".

\section{METODE}

Metode sangat diperlukan dalam sebuah penelitian. Penggunaan metode dalam peneilitan desesuaikan dengan masalah dan tujuan penelitian. Untuk memperoleh data yang sesuai dengan tujuan penelitian ini maka menggunakan metode experiment dengan tipe pretest - posttest (Sugiyono, 2014).

Metode Experimen mengadakan kegiatan percobaan terhadap varaibel - variabel yang diselidiki, untuk mendapatkan suatu hasil dari suatu sebab akibat dalam kondisi tertentu.

Variabel penelitian meliputi dua variable bebas dan satu variable terikat, variable bebas terdiri dari pengaruh latihan otot lengan, sedangkan variable terikat adalah kemampuan smash dalam permainan bola voli.

Sebelum melakukan eksperimen, seorang peneliti harus dapat merumuskan terlebih dahulu langkah - langkah yang akan ditempuh, supaya dalam pelaksanaannya dapat berjalan lancar dan sesuai dengan yang diharpakan. Rancangan kegiatan untuk mengatur langkah-langkah yang akan ditempuh dalam melaksanakan penelitian disebut desain.

Desain pretes-posttes satu kelompok juga termasuk pre-eksperimen. Pada desain ini dilakukan pretes untuk mengetahui keadaan awal subjek sebelum diberi perlakuan sehingga peneliti dapat mengetahui kondisi subjek yang diteliti sebelum atau sesudah diberi perlakuan yang hasilnya dapat dibandingkan atau dilihat perubahannya.

Rancangan one group pretest-posttest design ini terdiri atas satu kelompok yang telah ditentukan. Di dalam rancangan ini dilakukan tes sebanyak dua kali, yaitu sebelum diberi perlakuan disebut prates dan sesudah perlakuan disebut pas-cates. Adapun pola penelitian metode one group pretest-posttest design menurut (Sugiyono, 2014). Desain yang dipergunakan dalam penelitian ini adalah desain pre-test post-test. Adapun gambaran mengenai desain tersebut dapat dilihat pada gambar berikut: 

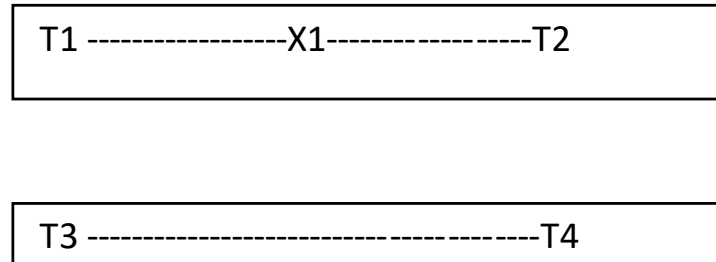

\section{Gambar 1}

Desain Pre-Test Post-Test

(Sugiyono, 2014)

Keterangan :

$\mathrm{T} 1$ = Tes aw al kelompok latihan kekuatan otot lengan.

$\mathrm{T} 2=$ Tes akhir kelompok latihan kekuatan otot lengan.

$\mathrm{T} 3=$ Tes aw al kelompok kontrol.

T4 = Tes akhir kelompok kontrol.

$\mathrm{X} 1$ = Latihan kekuatan otot lengan .

Tujuan penelitian ini adalah untuk mengetahui adanya pengaruh latihan otot lengan terhadap kemampuan smash dalam permainan bola voli. Penelitian ini termasuk kedalam penelitian eksperiment. Berdasarkan banyak disain dalam penelitian eksperimen maka peneliti ingin menggunakan penelitian quasi eksperimen yang bertujuan untuk melihat pengaruh latihan otot lengan terhadap kemampuan smash dalam permainan bola voli dengan cara memberikan perlakuan-perlakuan tertentu pada kelas eksperimen.

Prosedur yang pertama yang dilakukan peneliti adalah meminta izin ke kurukulum dan kepala sekolah SMPN 1 BOJONGPICUNG terlebih dahulu bahwa akan mengadakan penelitian disekolah tersebut apakah diizinkan atau tidak. Berdasarkan kordinasi dengan pihak kurikulum dan kepala sekolah, Peneliti diberikan pemain yang jumlahnya sebanyak 30 dengan berbagai pertimbangan dan jumlah yang tidak terlalu banyak karena masih di masa pandemic ini. Dimana jumlah tersebut di berikan oleh peneliti dengan kelas eksperimen Sebelum melakukan penelitian menyerahkan surat izin penelitian dari kampus STKIP Pasundan Cimahi dan meminta surat balasan penelitian dari SMPN 1 BOJONGPICUNG bahwa diizinkan untuk melakukan penelitian di SMPN 1 BOJONGPICUNG. Untuk materi yang digunakan dalam penelitian ini peneliti melakukan kordinasi dengan salah satu pelatih diekstrakurikuler diSMPN 1 BOJONGPICUNG. Setelah melakukan kordinasi beberapakali terkait program yang akan dijadikan penelitian yaitu program latihan otot lengan. setelah waktu penelitian dan materi latihan untuk penelitian sudah jelas, peneliti segera menyusun instrument penelitian dan perangkat-perangkat yang dibutuhkan selama penelitian. 
Penelitian dilaksanakan pada tanggal 14 Desember 2020 - 22 Januari 2021. Penelitian berjalan sesuai dengan program latihan yang telah dibuat oleh peneliti (terlampir 1). Peneliti dimulai dengan kegiatan pretes (tes awal) dimana siswa belum diberikan treatment.

Penelitian ini dilakukan di SMPN 1 BOJONGPICUNG dengan mengambil populasi seluruh siswa SMPN 1 BOJONGPICUNG tersebut yang umur 14-15 tahun. Disini peneliti mengambil sampel sebanyak 30 orang dan 15 orang menggunakan latihan otot lengan (kelompok eksperimen), dan 15 orang tidak menggunakan latihan otot lengan (kelompok kontrol). Dalam penelitian ini peneliti memberikan perlakuan yang berupa latihan otot lengan,Data dalam penelitian ini diperoleh melalui beberapa metode, yaitu metode dokumentasi, metode Pree-test,Post-test. Adapun hasil Pre-Test dan Post-Test hasil Ball-put Medicine sebagai berikut :

Tabel 1. Hasil Tabulasi Kriteria Penilaian

Test Ball-put Medicine Awal dan Test Akhir kelompok eksperinen

\begin{tabular}{clccc}
\hline No & Nama & $\begin{array}{c}\text { Tes awal } \\
\text { ball-put } \\
\text { medicine }\end{array}$ & $\begin{array}{c}\text { Tes akhir ball- } \\
\text { put medicine }\end{array}$ & Peningkatan \\
\hline 1 & Ulwan ubaidilah & 4,00 & 6,00 & 2,00 \\
2 & Ilham ramdani & 4,30 & 5,70 & 1,40 \\
3 & Trirama & 4,40 & 6,23 & 1,38 \\
4 & Rizki A & 4,60 & 6,22 & 1,62 \\
5 & Syahnapin & 3,70 & 5,60 & 1,90 \\
6 & Gema azar & 4,00 & 5,80 & 1,80 \\
7 & Eric ardiansyah & 3,80 & 5,60 & 1,80 \\
8 & Gairul latif & 3,70 & 5,60 & 1,90 \\
9 & M alugraha & 3,71 & 5,71 & 2,00 \\
10 & Muhamad agus & 4,40 & 6,40 & 2,00 \\
11 & Aiman muhammad & 4,40 & 6,40 & 2,00 \\
12 & Ilham maulana & 5,00 & 6,38 & 1,38 \\
13 & Muhammad insan & 3,95 & 5,95 & 2,00 \\
14 & Dafa aditya & 4,80 & 6,80 & 2,00 \\
15 & Asep zidan & 4,32 & 6,75 & 2,38
\end{tabular}

Maka dari data awal diatas dapat disimpilkan sebanyak 1 orang mengalami peningkatan sebesar 2,38\%, 1 orang 1,40\%, 1 orang 1,62\%, 2 orang 1,80\%, 2 orang $1,90 \%$, dan 6 orang $2,00 \%, 2$ orang 1,38\%, untuk tes awal rata-rata pemain mendapat 4,20 poin, dan untuk tes akhir rata-rata pemain mendapatkan 6,07 poin maka peningkatan pemain yang menggunakan latihan kekuatan otot lengan sebesar $1,87 \%$.

Tabel 2. Hasil Tabulasi Kriteria Penilaian Test Ball-put Medicine Awal dan Test Akhir kelompok kontrol

\begin{tabular}{llccc}
\hline No & Nama & $\begin{array}{c}\text { Tes awal } \\
\text { ball-put } \\
\text { medicine }\end{array}$ & $\begin{array}{c}\text { Tes akhir ball- } \\
\text { put medicine }\end{array}$ & Peningkatan \\
\hline 1 & Muhamad sopiyan & 4,40 & 6,23 & 1,38 \\
2 & Muhamad azis & 4,30 & 5,70 & 1,40 \\
3 & Qhoirul latif & 4,40 & 6,23 & 1,38 \\
4 & Tio khati nuansa & 4,60 & 6,22 & 1,62 \\
5 & Abdul racman isa & 3,70 & 5,60 & 1,90 \\
6 & Muhmad wira aditya & 4,00 & 5,80 & 1,80
\end{tabular}




\begin{tabular}{cllll}
7 & Asep septiun s & 3,80 & 5,60 & 1,80 \\
8 & Rizky alpiansyah & 3,70 & 5,60 & 1,90 \\
9 & Maxrian & 4,40 & 6,23 & 1,38 \\
10 & Dimas dwi rizka & 4,40 & 6,23 & 1,38 \\
11 & Asep ahmad & 4,40 & 6,23 & 1,38 \\
12 & M laham aganda & 5,00 & 6,38 & 1,38 \\
13 & M sapta aziz & 4,00 & 5,80 & 1,80 \\
14 & Yusup cahya ajis & 3,80 & 5,60 & 1,80 \\
15 & Adris dal robi & 4,40 & 6,23 & 1,38 \\
\hline
\end{tabular}

Maka dari data awal diatas dapat disimpilkan sebanyak 1 orang mengalami peningkatan sebesar $1,40 \%, 1$ orang $1,62 \%, 4$ orang 1,80\%, 2 orang 1,90\%, 7 orang $1,38 \%$, untuk tes awal rata-rata pemain mendapat 4,22 poin, dan untuk tes akhir rata-rata pemain mendapatkan 5,97 poin maka peningkatan pemain yang menggunakan latihan kekuatan otot lengan sebesar 1,75\%. Adapun hasil Pre-Test dan Post-Test hasil smash dalam permainan bola voli sebagai berikut :

Tabel 3. Hasil Tabulasi Kriteria Penilaian Test Kemampuan spike Awal dan Test Akhir kelompok eksperimen

\begin{tabular}{clccc}
\hline No & Nama & $\begin{array}{c}\text { Tes awal spike/ } \\
\text { smash }\end{array}$ & $\begin{array}{c}\text { Tes akhir } \\
\text { spike / smash }\end{array}$ & Peningkatan \\
\hline 1 & Ulwan ubaidilah & 14 & 19 & 5 \\
2 & Ilham ramdani & 17 & 24 & 6 \\
3 & Trirama & 16 & 24 & 8 \\
4 & Rizki A & 17 & 24 & 7 \\
5 & Syahnapin & 18 & 22 & 5 \\
6 & Gema azar & 17 & 24 & 7 \\
7 & Eric ardiansyah & 16 & 22 & 6 \\
8 & Gairul latif & 18 & 21 & 3 \\
9 & M alugraha & 15 & 23 & 8 \\
10 & Muhamad agus & 15 & 22 & 7 \\
11 & Aiman muhammad & 17 & 24 & 7 \\
12 & Ilham maulana & 18 & 22 & 4 \\
13 & Muhammad insan & 18 & 21 & 3 \\
14 & Dafa aditya & 18 & 22 & 4 \\
15 & Asep zidan & 18 & 22 & 4 \\
\hline
\end{tabular}

Maka dari data awal diatas dapat disimpilkan sebanyak 4 orang mengalami peningkatan sebesar $4 \%, 4$ orang $3 \%, 3$ orang $5 \%, 2$ orang $2 \%$, dan 2 orang $6 \%$, untuk tes awal rata-rata pemain mendapat 16,80 poin, dan untuk tes akhir rata-rata pemain mendapatkan 22,40 poin maka peningkatan pemain yang menggunakan latihan kekuatan otot lengan sebesar $5,6 \%$. 
Tabel 4. Hasil Tabulasi Kriteria Penilaian

Test Kemampuan spike Awal dan Test Akhir kelompok kontrol

\begin{tabular}{clccc}
\hline No & Nama & $\begin{array}{c}\text { Tes awal } \\
\text { spike / smash }\end{array}$ & $\begin{array}{c}\text { Tes akhir } \\
\text { spike / } \\
\text { smash }\end{array}$ & Peningkatan \\
\hline 1 & Muhamad sopiyan & 17 & 19 & 2 \\
2 & Muhamad azis & 20 & 22 & 2 \\
3 & Qhoirul latif & 17 & 20 & 3 \\
4 & Tio khati nuansa & 16 & 19 & 3 \\
5 & Abdul racman isa & 14 & 18 & 4 \\
6 & Muhmad wira aditya & 14 & 17 & 3 \\
7 & Asep septiun s & 15 & 20 & 5 \\
8 & Rizky alpiansyah & 17 & 21 & 4 \\
9 & Maxrian & 12 & 21 & 9 \\
10 & Dimas dwi rizka & 18 & 22 & 4 \\
11 & Asep ahmad & 14 & 19 & 5 \\
12 & M laham aganda & 18 & 22 & 4 \\
13 & M sapta aziz & 18 & 19 & 3 \\
14 & Yusup cahya ajis & 18 & 22 & 4 \\
15 & Adris dal robi & 18 & 22 & 4 \\
\hline
\end{tabular}

Maka dari data awal diatas dapat disimpilkan sebanyak 6 orang mengalami peningkatan sebesar $4 \%, 4$ orang $3 \%$, 2 orang $5 \%, 1$ orang $9 \%$, dan 2 orang $2 \%$, untuk tes awal rata-rata pemain mendapat 16,40 poin, dan untuk tes akhir rata-rata pemain mendapatkan 20,20 poin maka peningkatan pemain yang menggunakan latihan kekuatan otot lengan sebesar $3,8 \%$.

Langkah pertama yang penulis lakukan adalah menyusun data yang telah diperoleh. dengan pengolahan menggunakan bantuan komputer program M.S Excel sebagai data mentah dan SPSS versi 25 IBM sebagai pengolahan datanya. Hasilnya sebagai berikut :

Tabel 5. Tes Spike/Smash

\begin{tabular}{|c|c|c|c|c|c|c|c|c|}
\hline \multicolumn{9}{|c|}{ Descriptive Statistics } \\
\hline & $\mathrm{N}$ & Range & Minimum & Maximum & $\mathrm{Me}$ & & $\begin{array}{c}\text { Std. } \\
\text { Deviation }\end{array}$ & Variance \\
\hline & Statistic & Statistic & Statistic & Statistic & Statistic & d. Error & Statistic & Statistic \\
\hline $\begin{array}{l}\text { pretes_spike_eksperime } \\
\mathrm{n}\end{array}$ & 15 & 4 & $\begin{array}{ll}4 & 14\end{array}$ & $\quad 18$ & 16,80 & ,341 & 1,320 & 1,743 \\
\hline $\begin{array}{l}\text { posttes_spike_eksperim } \\
\text { en }\end{array}$ & 15 & 5 & 19 & 24 & 22,40 &, 375 & 1,454 & 2,114 \\
\hline pretes_spike_kontrol & 15 & 8 & 12 & 20 & 16,40 &, 559 & 2,165 & 4,686 \\
\hline postes_spike_kontrol & 15 & 5 & 17 & 22 & 20,20 & ,428 & 1,656 & 2,743 \\
\hline Valid N (listwise) & 15 & & & & & & & \\
\hline
\end{tabular}


Berdasarkan pada table di atas diketahui pengaruh latihan kekuatan otot lengan terhadap kemampuan smash hasil pre test kelompok eksperimen dengan rata-rata 16,80 dan standar deviasi 1,320, untuk post test dengan rata-rata 22,40 dan standar deviasi 2,114. Sedangkan terhadap kelompok kontrol hasil pre test rata-rata 16,40 dan standar deviasi 2,165. Untuk post test kelompok kontrol dengan rata-rata 20,20 dan standar deviasi 1,656 .

Tabel 6. Tes Ball-Put Medicine

Hasil Penghitungan Rata-Rata Dan Simpangan Baku

\begin{tabular}{|c|c|c|c|c|c|c|c|c|}
\hline \multicolumn{9}{|c|}{ Descriptive Statistics } \\
\hline & \multirow{3}{*}{$\begin{array}{c}\mathrm{N} \\
\text { Statistic }\end{array}$} & \multirow{3}{*}{$\begin{array}{c}\text { Range } \\
\text { Statistic }\end{array}$} & \multirow{3}{*}{$\begin{array}{l}\text { Minimum } \\
\text { Statistic }\end{array}$} & \multirow{3}{*}{$\begin{array}{l}\text { Maximum } \\
\text { Statistic }\end{array}$} & \multirow{2}{*}{\multicolumn{2}{|c|}{ Mean }} & \multirow{3}{*}{$\begin{array}{c}\text { Std. } \\
\text { Deviation } \\
\text { Statistic }\end{array}$} & \multirow{3}{*}{$\begin{array}{l}\text { Variance } \\
\text { Statistic }\end{array}$} \\
\hline & & & & & & & & \\
\hline & & & & & Statistic & Std. Error & & \\
\hline pretes_ballup_medi & 15 & 1,3 & 3,7 & 5,0 & 4,20 &, 1057 &, 4094 &, 168 \\
\hline cine_eksperimen & & & & & & & & \\
\hline $\begin{array}{l}\text { posttes_ballup_medi } \\
\text { cine_eksperimen }\end{array}$ & 15 & 1,2 & 5,6 & 6,8 & 6,07 &, 1064 & ,4122 &, 170 \\
\hline $\begin{array}{l}\text { pretes_ballup_medi } \\
\text { cine_kontrol }\end{array}$ & 15 & 1,3 & 3,7 & 5,0 & 4,22 & ,0962 & ,3726 & ,139 \\
\hline $\begin{array}{l}\text { posttes_ballup_medi } \\
\text { cine_kontrol }\end{array}$ & 15 & ,8 & 5,6 & 6,4 & 5,97 & ,0791 & ,3063 & ,094 \\
\hline Valid N (list wise) & 15 & & & & & & & \\
\hline
\end{tabular}

Berdasarkan pada table di atas diketahui pengaruh latihan kekuatan otot lengan terhadap kemampuan smash, hasil pre test kelompok eksperimen dengan rata-rata 4,20 dan standar deviasi 0,4094, untuk post test dengan rata-rata 6,07 dan standar deviasi 0,4122. Sedangkan terhadap kelompok kontrol hasil pre test rata-rata 4,22 dan standar deviasi 0,3726, untuk post test kelompok kontrol dengan rata-rata 5,97 dan standar deviasi 0,3063 .

Berdasarkan hasil penelitian didapatkan bahwa untuk tes awal kelompok eksperimen rata-rata pemain mendapat 16,80 poin, dan untuk tes akhir kelompok eksperimen rata-rata pemain mendapatkan 22,40 poin, maka peningkatan pemain yang menggunakan latihan kekuatan otot lengan sebesar 5,6\%, sedangkan untuk tes kelompok kontrol aw al rata-rata pemain mendapat 16,40 poin, dan untuk tes akhir rata-rata pemain mendapatkan 20,20 poin maka peningkatan pemain yang tidak menggunakan latihan kekuatan otot lengan sebesar $3,8 \%$.

\section{Pembahasan}

Kelompok latihan otot lengan memiliki peningkatan yang lebih besar dibandingkan dengan kelompok control, namun dari sisi peningkatan berdasarkan pengujian tes awal dan tes akhir tidak terjadi peningkatan baik dari kelompok otot lengan maupun kelompok kontrol. Hal ini disebabkan oleh karena faktor-faktor yang 
mempengaruhi terhadap hasil penelitian yang dilakukan. Faktor-faktor yang mempengaruhi penelitian tersebut adalah sebagai berikut:

Latihan otot lengan memiliki karakteristik yang sesuai dengan bentuk latihan untuk meningkatkan kemampuan karena latihan otot lengan merupakan salah satu bentuk latihan pliometrik. Kesesuaian dengan prinsip-prinsip gerak tersebut memacu siswa secara fisiologis untuk siap melakukan teknik gerak yang diharapkan pada saat ada rangsangan yang diberikan. Hal ini terjadi ketika dalam permainan diberikan umpan untuk dilakukan spike dalam permainan bola voli (Otot et al., 2012)

At let bola voli harus memiliki komponen kondisi fisik yang mendukung terhadap aktivitas olahraga yang dilakukannya. Komponen kondisi fisik yang baik memungkinkan atlet lebih berkualitas dalam berbagai hal. Atlet dengan komponen kondisi fisik yang baik dapat meningkatkan berbagai kemampuan terutama kemampuan fisiologis. Peranan kondisi fisik yang baik dapat menunjang juga terhadap peningkatan kemampuan secara teknik yang berimbas pada penguasaan suatu ketemapilan teknik dalam cabang olahraga bola voli. Hal ini seperti yang diungkapkan oleh (Harsono 2011) bahwa:

Kalau kondisi fisik baik maka:

1. Akan ada peningkatan dalam kemampuan sistem sirkulasi dan kerja jantung.

2. Akan ada peningkatan dalam kekuatan, kelentukan, stamina, kecepatan, dan lainlain komponen kondisi fisik.

3. Akan ada ekonomi gerak yang lebih baik pada waktu latihan.

4. Akan ada pemulihan yang lebih cepat dalam organ-organ tubuh setelah latihan.

Pengertian akan ada ekonomi gerak adalah bahwa atlet akan mengalami suatu kondidsi di mana dia akan mampu melakukan suatu pergerakan dengan sangat halus dengan hasil yang optimal

\section{KESIMPULAN}

Pada pembahasan ini peneliti memaparkan hasil penelitian yang telah dilakukan mengenai pengaruh latihan kekuatan otot lengan terhadap kemampuan smash dalam permainan bola voli pada siswa ekstrakurikuler di SMPN 1 Bojongpicung Kabupaten Cianjur, dari hasil demikian artinya peneliti dapat menyimpulkan bahwa penggunaan latihan kekuatan otot lengan mempunyai pengaruh terhadap peningkatan kemampuan smash dalam permainan bola voli pada siswa setelah mendapat perlakuan selama 18 kali pertemuan. Lalu dari hasil analisis data dengan cara statistik deskriptif dengan perhitungan persentase. 
Hasil penelitian menunjukan bahwa sebanyak 15 siswa dengan latihan kekuatan otot lengan sebesar 5,6\%, sedangkan peningkatan pemain yang tidak menggunakan latihan kekuatan otot lengan sebesar 3,8\%., maka dari itu peneliti dapat menyimpulkan bahwa penggunaan latihan kekuatan otot lengan mempunyai pengaruh yang signifikan terhadap peningkatan kemampuan smash dalam permainan bola voli pada siswa setelah mendapat perlakuan selama 18 kali pertemuan.

\section{DAFTAR PUSTAKA}

Beutelstahl, D. (2015). Belajar Bermain Bola Voli. Pionir Jaya.

Chan, F. (2012). Strength Training (Latihan Kekuatan). Cerdas Sifa, 1(1), 1-8. https://online-journal.unja.ac.id/index.php/csp/article/view/703

Dr. Bafirman HB, M.Kes., A., \& Dr. Asep Sujana Wahyuni, S.Si., M. P. (2019). pembetukan kondisi fisik. rajawali pers.

Effendi, H. (2016). Peranan psikologi olahraga dalam meningkatkan prestasi atlet. Nusantara (Jurnal Ilmu Pengetahuan Sosial), 1, 23-30.

Ilmiah, A., Studi, P., Jasmani, P., Dan, K., Keolahragaan, J. I., Keguruan, F., Ilmu, D. A. N., \& Tanjungpura, U. (2016). PENINGKATAN PASSING ATAS BOLA VOLI MELALUI MEDIA BOLA KARET DI SDN 09 SINGKAM.

Otot, K., Terhadap, L., Sasaran, K., \& Open, P. (2012). Pendidikan Kepelatihan Olahraga, Fakultas Ilmu Keolahragaan, UNESA tinggi badan, kekuatan otot lengan terhadap ketepatan sasaran pukulan open spike dalam permainan bolavoli . yang signifikan terhadap ketepatan sasaran pukulan open spike. arm muscle strength to the accuracy of the hit target open spike in volleyball. method of this study was a quantitative, data processing was done by using SPSS 16.00. The data retrieval. $1-5$.

Seminar, P., Penelitian, H., Kesejahteraan, U., Penelitian, L., \& Negeri, U. (2017). Penerapan variasi latihan. September, 99-103.

Suarsana, I. M., \& Baan, A. B. (2013). Pengaruh Latihan Kekuatan Otot Lengan Terhadap Ketepatan Smash Dalam Permainan Bola Voli Club Sigma Palu. Tadulako Journal Sport Sciences And Physical Education, 1(3), 1-11. http://jurnal.untad.ac.id/jurnal/index.php/PJKR/article/view/2164

Sugiyono. (2014). METODE PENELITIAN ILMIAH. http://ir.obihiro.ac.jp/dspace/handle/10322/3933 